Mongolian Academy of Sciences
Mongolian Journal of Chemistry
Institute of Chemistry \& Chemical Technology

\title{
Some properties of testicular hyaluronidases
}

\author{
Enkhmaa Ts., Purev D., Bayarmaa $\mathbf{J}^{1}$ \\ ${ }^{1}$ NUM, School of Biology and Biotechnology \\ e-mail: enhma_87@yahoo.com
}

\begin{abstract}
The properties $\left(\mathrm{pH}_{\mathrm{opt}}, \mathrm{T}_{\mathrm{opt}}, \mathrm{K}_{\mathrm{m}}\right.$, temperature, acid and base stability of the enzyme activity) of hyaluronidase prepared from testes of bovine, horse, pig and antelope were determined.
\end{abstract}

Keywords: hyaluronidases, hyaluronic acid, glycosaminoglycan

\section{Introduction}

7 he hyaluronidases (EC 3.2.1.35) have been detected in many mammalian tissues and organs. Some bacteria such as Streptococcus pyogenes and Clostridium perfringens produce hyaluronidase (Ohya T., 1970). Hyaluronidase resists spreading of venoms and virulence of bacteria and may play a role in cancer metastasis and angiogenesis (Beckenlehner K., 1992). Therefore it is used in medicine (Schomberg D., 1991). There are many beneficial effects of hyaluronidase in the biological function.

Mammalian oocytes are surrounded by several layers of cells embedded in extracellular matrix which contains protein and hyaluronic acid. That is why hyaluronidase degrades these layers. This process helps to spermatozoon fertelizing egg (Dandekar P., 1992). The substrate of hyaluronidase is hyaluronic acid (HA). It is a glycosaminoglycan with high molecular weight linear polymer built of large numbers of repeating units consisting of $[-D-$ glucuronic acid- $\beta 1,3-N$-acetyl- $D$ glucosamine- $\beta 1,4-]_{\mathrm{n}}$ (Laurent T.C., 1992).

\section{Experimental}

Materials and chemicals: The testes of bovine, pig and horse were purchased from "MAX IMPEX" company and testes of antelope were taken from Bayandun sum of Dornod aimag.

Determination of enzyme activity: The enzyme activity was determined by classic turbidimetric assay (Yang C., 1975). This method is based on the estimation due to an interaction between albumin and HA. Mixture of $0.5 \mathrm{ml}$ of hyaluronate solution (0.04-0.32 $\mathrm{mg} / \mathrm{ml}$ of HA (Wortington) in $0.2-1.0 \mathrm{ml}$ of $0.1 \mathrm{M}$ sodium phosphate buffer with $\mathrm{pH} 5.3$ which contains $0.15 \mathrm{M} \mathrm{NaCl}$ ) and $0.5 \mathrm{ml}$ of testicular extract was incubated at $37^{\circ} \mathrm{C}$ for 25 minutes. Then $9 \mathrm{ml}$ of albumin was added to the solution and was being stayed for 10 minutes at room temperature.

The color development was measured at 540 $\mathrm{nm}$ against control solution by the spectrophotometer. The results were compared with the standard curve.

Plotting the standard curve: The solution of HA was heated for 5 minutes in a boiling water bath and $9 \mathrm{ml}$ of albumin was added to test tubes and was measured at $540 \mathrm{~nm}$ against control solution. 
Determination of the protein concentration:

Protein concentration in solutions was determined by the biuret reaction(Tsevegsuren N., 2001), $\mathrm{pH}_{\mathrm{opt}}$ was determined along with the enzyme activity in buffer indicating various $\mathrm{pH}(2-11), \mathrm{T}_{\mathrm{opt}}$ by the enzyme activity at $20-60^{\circ} \mathrm{C}, \mathrm{K}_{\mathrm{m}}$ by Lineweaver-Burk plot, temperaturedependence by denaturation time of enzyme activity at various temperatures, acid influence on enzyme activity was determined by enzyme activity at $\mathrm{pH} 1$, while base influence on enzyme activity was determined at pH 10 (Purev D., 2003).

\section{Results and discussion}

The testes of bovine, pig, antelope and horse were cleaned from lipid mass and connective tissue following with cut and mash. Hyaluronidase activity and protein concentrations were estimated in all samples. Results are shown in the Table 1.

Table 1. Protein concentration and hyaluronidase activity in all samples

\begin{tabular}{|l|l|c|c|}
\hline № & Sample & $\begin{array}{c}\text { Protein } \\
\text { concentration, \% }\end{array}$ & $\begin{array}{c}\text { Enzyme } \\
\text { activity, units* }\end{array}$ \\
\hline 1 & Bovine & $4.57 \pm 0.74$ & $13.76 \pm 1.59$ \\
\hline 2 & Horse & $4.00 \pm 0.82$ & $14.28 \pm 1.86$ \\
\hline 3 & Antelope & $3.45 \pm 0.45$ & $20.78 \pm 6.41$ \\
\hline 4 & Pig & $4.80 \pm 0.49$ & $11.29 \pm 1.13$ \\
\hline \multicolumn{4}{|c}{ Note: *300 units for Sigma pure hyaluronidase }
\end{tabular}

Results indicated that pig testicular samples contained much protein, while the testicular protein of the antelope was lower than other samples by $0.55-1.35 \%$. However the enzyme activity of the antelope was the highest than others (1.46-1.84 times more active in comparison with other samples).

The temperature influence on testicular hyaluronidase activity was assayed at $\mathrm{T}=20^{\circ} \mathrm{C}-60^{\circ} \mathrm{C}$. The $\mathrm{T}_{\text {opt }}$ was determined at $25-30^{\circ} \mathrm{C}$ for all samples, except pig's hyaluronidase, which was completely denaturated.The optimal $\mathrm{pH}$ of hyaluronidase of all samples were determined at $\mathrm{pH} 4$ and pH8-9 (Table 2, Fig 1 and Table 3, Fig 2 ).

Table 2. Temperature influence on enzyme activity

\begin{tabular}{|c|c|c|c|}
\hline \multirow{2}{*}{$\mathrm{T},{ }^{0} \mathrm{C}$} & \multicolumn{3}{|c|}{ Relative activity, \% } \\
\cline { 2 - 4 } & Bovine & Antelope & Horse \\
\hline 20 & 84.5 & 84.6 & 91.8 \\
\hline 25 & 100 & 100 & 100 \\
\hline
\end{tabular}

\begin{tabular}{|l|l|l|l|}
\hline 30 & 100 & 100 & 100 \\
\hline 35 & 89.7 & 96.3 & 94.1 \\
\hline 40 & 72.5 & 83.2 & 80.1 \\
\hline 45 & 64.5 & 71.9 & 73.5 \\
\hline 50 & 58.4 & 70.0 & 62.3 \\
\hline 55 & 56.7 & 62.1 & 52.9 \\
\hline 60 & 56.0 & 58.3 & 43.7 \\
\hline
\end{tabular}

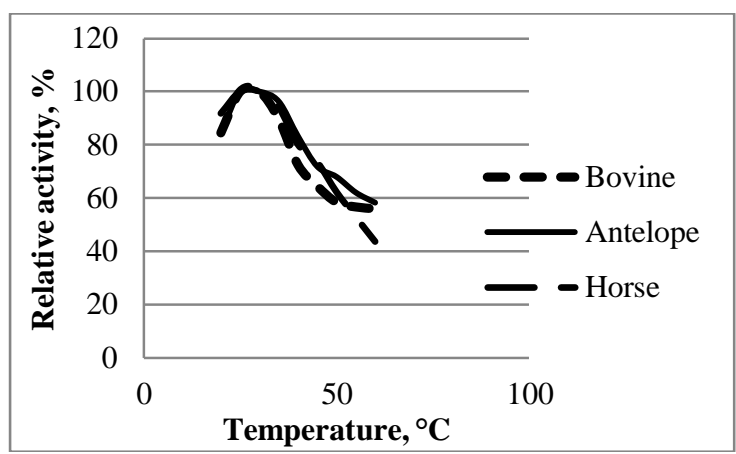

Figure1. Temperature influence on enzyme activity

Table 3. $\mathrm{pH}$ influence on enzyme activity

\begin{tabular}{|c|c|c|c|c|}
\hline \multirow{2}{*}{$\mathrm{pH}$} & \multicolumn{4}{|c|}{ Relative activity, \% } \\
\cline { 2 - 5 } & $\begin{array}{c}\text { Bovine } \\
(6)\end{array}$ & $\begin{array}{c}\text { Antelope } \\
(3)\end{array}$ & $\begin{array}{c}\text { Horse } \\
(5)\end{array}$ & $\begin{array}{c}\text { Pig } \\
(5)\end{array}$ \\
\hline 2 & $78.0 \pm$ & $93.4 \pm$ & $52.2 \pm$ & $82.9 \pm$ \\
\hline 3 & $92.0 \pm$ & $97.9 \pm$ & $65.2 \pm$ & $86.6 \pm$ \\
\hline 4 & $100 \pm$ & $100 \pm$ & $100 \pm$ & $100 \pm$ \\
\hline 5 & $56.8 \pm$ & $76.6 \pm$ & $73.2 \pm$ & $78.3 \pm$ \\
\hline 6 & $44.8 \pm$ & $72.5 \pm$ & $61.8 \pm$ & $65.2 \pm$ \\
\hline 7 & $57.1 \pm$ & $77.3 \pm$ & $71.7 \pm$ & $65.5 \pm$ \\
\hline 8 & $58.2 \pm$ & $78.6 \pm$ & $77.6 \pm$ & $66.4 \pm$ \\
\hline 9 & $53.0 \pm$ & $77.4 \pm$ & $89.5 \pm$ & $59.7 \pm$ \\
\hline 10 & $43.4 \pm$ & $72.8 \pm$ & $87.7 \pm$ & $45.3 \pm$ \\
\hline 11 & $37.5 \pm$ & $70.6 \pm$ & $75.7 \pm$ & $37.7 \pm$ \\
\hline
\end{tabular}

Note: Figures in bracket are the number of repeated experiments

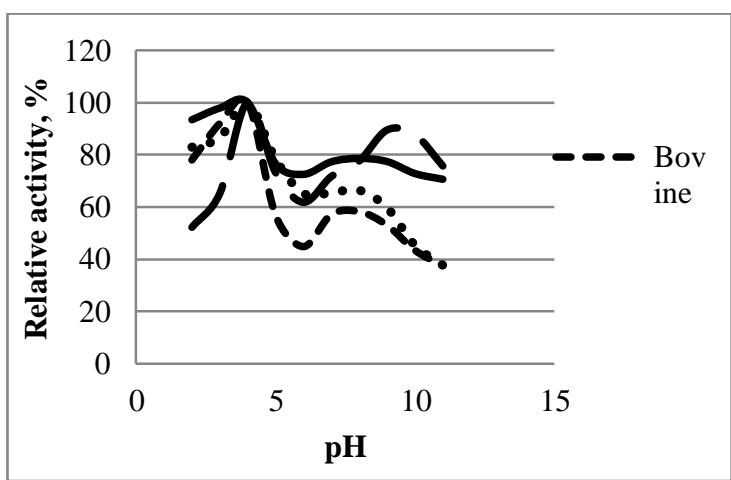

Figure 2. $\mathrm{pH}$ influence the enzyme activity.

Two meanings of $\mathrm{pH}_{\text {opt }}$ for testicular hyaluronidase were detected. Those results were same as researchers' findings who found the enzyme polymorphism (Cevallos M.A. et all, 1992). The $\mathrm{pH}_{\mathrm{opt}}$ range for antelope hyaluronidase was wide, while for horse enzyme it was narrower than other samples. 
For bovine and pig hyaluronidase the same values of $\mathrm{pHopt}$ were determined. Base influence on the enzyme activity was at first estimated at $\mathrm{pH}=9$ after incubation for 120 minutes. Here no changes were observed. Then at $\mathrm{pH}=10$ after incubating for 60 minutes enzyme activity was decreased. (Table 4).

Table 4. Base influence on the enzyme activity, $\mathrm{pH}=10$

\begin{tabular}{|c|c|c|c|}
\hline \multirow{2}{*}{$\begin{array}{c}\text { Inactivation } \\
\text { time,minutes }\end{array}$} & \multicolumn{3}{|c|}{ Relative activity, \% } \\
\cline { 2 - 4 } & Bovine & Antelope & Horse \\
\hline 0 & 100 & 100 & 100 \\
\hline 60 & 100 & 95.3 & 99.5 \\
\hline 120 & 97.7 & 88.2 & 97.2 \\
\hline 180 & 89.4 & 81.2 & 94.4 \\
\hline 240 & 84.7 & 76.5 & 86.2 \\
\hline
\end{tabular}

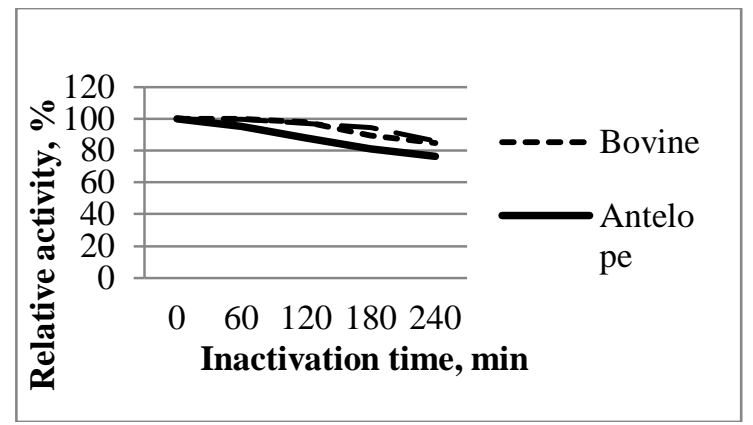

Figure 3. Base influence on enzyme activity

The base influence on the enzyme activity was estimated after incubation for 240 minutes. While three samples (bovine, horse, antelope) on $\mathrm{pH}=10$ were being observed and measured within each 60 minutes at $25^{\circ} \mathrm{C}$. In the result enzyme activity decreased until $84.7 \%, 76.5 \%, 86.2 \%$ (Figure 3).

Figure 4. Hyaluronidases base inactivation reaction order

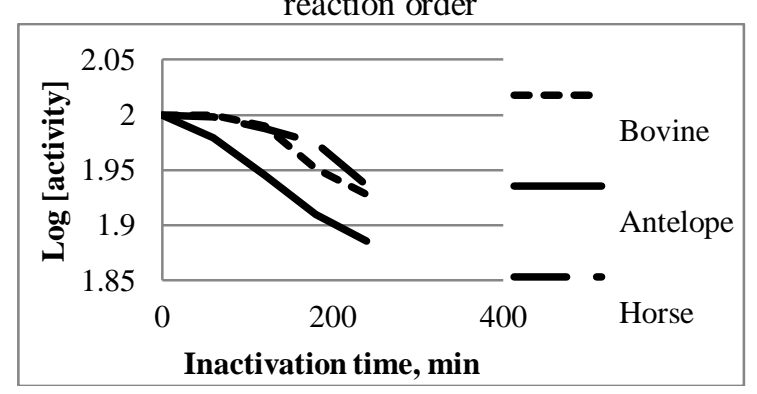

Base inactivation reaction order for bovine, horse and antelope hyaluronidases were calculated as $n$-th order reaction (Figure 4).
Table 5. Acid influence on the enzyme activity, $\mathrm{pH}=1.0$

\begin{tabular}{|c|c|c|c|c|}
\hline & \multicolumn{4}{|c|}{ Relative activity, \% } \\
\hline № & $\begin{array}{c}\text { Time, } \\
\text { minutes }\end{array}$ & Bovine & Antelope & Horse \\
\hline 1 & 0 & 100 & 100 & 100 \\
\hline 2 & 30 & 17.65 & 0 & 12.9 \\
\hline 3 & 60 & 12.94 & - & 0 \\
\hline 4 & 90 & 8.24 & - & - \\
\hline 5 & 120 & 0 & - & - \\
\hline
\end{tabular}

The acid influence of enzyme activity was determined on three samples(bovine, horse, antelope) by incubated for 90 minutes within each 30 minutes at $\mathrm{pH}=1$. In the result bovine enzyme completely denaturated after 90 minutes, while horse enzyme after 60 minutes and antelope hyaluronidase after 30 minutes of incubation. Thus hyaluronidase is not stable at acid environment (Figure 5).

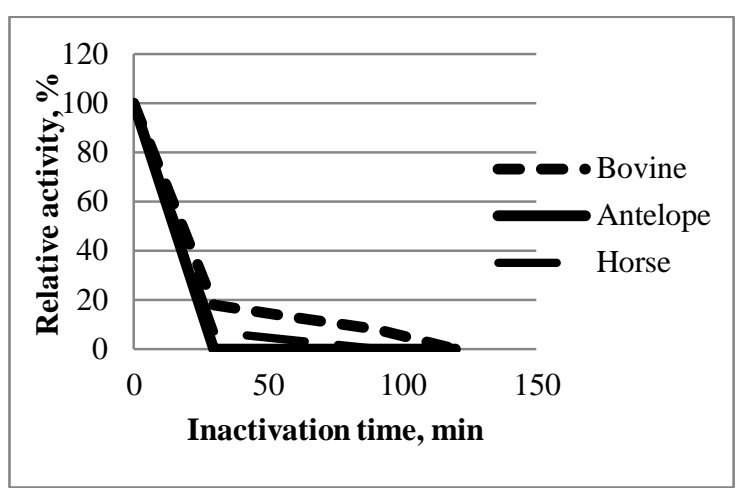

Figure 5. Acid influence on the enzyme activity

We have determined the $\mathrm{K}_{\mathrm{m}}$ meanings for bovine, horse and antelope hyaluronidase by Lineweaver-Burk plot. Which was calculated as $0.23 \mathrm{mg} / \mathrm{ml}$ for bovine enzyme, $0.48 \mathrm{mg} / \mathrm{ml}$ for antelope and $0.83 \mathrm{mg} / \mathrm{ml}$ for horse testicular hyaluronidase, respectively.

\section{Conclusions}

1. Results indicated that pig testicular samples contained much protein, while the testicular protein of the antelope was lower than other samples by $0.55-1.35 \%$. However the enzyme activity of the antelope was the highest than others.

2. $\mathrm{T}_{\mathrm{opt}}$ of hyaluronidase was in $25-30^{\circ} \mathrm{C}$ except pig's and $\mathrm{pH}_{\mathrm{opt}}$ at 4.0 for all four samples. 
3. The optimal $\mathrm{pH}$ of hyaluronidase of all samples were determined at $\mathrm{pH} 4$ and pH8-9.

4. $\mathrm{K}_{\mathrm{m}}$ meanings for bovine, horse and antelope hyaluronidase by LineweaverBurk plot. Which was calculated as 0.23 $\mathrm{mg} / \mathrm{ml}$ for bovine enzyme, $0.48 \mathrm{mg} / \mathrm{ml}$ for antelope and $0.83 \mathrm{mg} / \mathrm{ml}$ for horse testicular hyaluronidase, respectively.

\section{References}

1. Beckenlehner K., Banoke S., Bernhardt G. and Schiess W (1992). Hyaluronidase enhances the activity of adriamycin in breast cancer models in vitro and in vivo. J. Cancer Res. Clin. Oncol. 188: 591.

2. Cevallos M.A., Navarro-Duque C.,. Varela-Julia M, and Alagon A.C (1992). Molecular mass determination and assay of venom hyaluronidases by sodium dodecyl sulfate-polyacrylamide gel electrophoresis. Toxicon. 30: 925.
3. Dandekar P., Aggeler J., and Talbot P (1992). Structure, distribution and composition of the extracellular matrix of human oocytes and cumulus masses. Hum. Reprod. 7: 391.

4. Laurent T.C. and Fraser J.R.E. (1992) Hyaluronan, FASEB J. 6: 2397.

5. Ohya T. and Kanako Y. (1970) Novel hyaluronidase from Streptomyces. Biochem. Biophys. Acta 198: 607.

6. Purev D, Bayarmaa J. Enzymology (2003) Ulaanbaatar, pp 247-248, 291292

7. Schomberg D. and Salzmann M., eds. (1991) Enzyme Handbook. SpringerVerlag, Berlin.

8. Tsevegsuren N., Purev D. (2001) Bioorganic chemistry practices. Ulaanbaatar. p.76-81

9. Yang C. and Srivastava P.N. (1975) Purfication and properties of hyaluronidase from bull sperm. J. Biol. Chem. 250: 79. 